\title{
Tailoring the needs for a better living: an urban renewal scheme on low cost housing
}

\author{
A. F. Bakri ${ }^{1}$, S. S. Zubir ${ }^{1}$, Z. Samadi ${ }^{1}$ \& H. Osman ${ }^{2}$ \\ ${ }^{I}$ Department of Architecture, Faculty of Architecture, \\ Planning and Surveying, Universiti Teknologi Mara, Malaysia \\ ${ }^{2}$ Department of Development and Maintenance, \\ Universiti Kebangsaan, Malaysia
}

\begin{abstract}
Low cost housing has always been associated with a lot of problems such as insufficient number of parking, dirty, overcrowded, improper sanitation and high crime rate. This paper presents an alternative solution to redevelop one of the oldest Industrialized Building System (IBS) housing scheme in Riffle Range, Pulau Pinang, Malaysia. Situated within the peripheries of Georgetown, the plain and functional looking development consists of 9 blocks of flats with 3682 residential units accommodating more than 15,000 people. The one and twobedroom residential units were found not only insufficient in terms of habitable spaces but also have created unstable social conditions. The aim of this paper is to provide a design solution that creates better quality of life for the community. It focuses on incorporating IBS modular system in the new development by creating various possibilities and versatility of arranging units to overcome the monotonous look and also providing more residential units. It also provides a more conducive living with a more appropriate recreational and community spaces. By using recycle materials and adapting to the existing infrastructures, it is hoped that this urban renewal scheme will benefit the community and the stakeholders. Synoptic method of design was used where analysis were done, alternatives searched and comparisons were made to find the best solution to the problem. The results of the study showed that the issues can be solved by incorporating sustainable urban design approaches which will incorporates a vibrant, comfortable and sustainable environment for the residents.
\end{abstract}

Keywords: industrialized building system, modular, sustainable, low cost housing. 


\section{Introduction}

Housing is a basic need for every human being. It provides both physical and psychological needs which include shelter, comfort, security, privacy and sense of belonging for each individual. Every human has the right to adequate housing. The Istanbul Declaration on Human Settlement has clarified the right to adequate housing where the Government has to take necessary action in order to encourage, care for and make sure full understanding and consciousness of the right to adequate housing. The Heads of State and Government have 'reaffirm our commitment to the full and progressive realization of the right to adequate housing, as provided for international instrument' [1].

Meanwhile, low cost houses can be defined as housing for people with limited earning and household income. There are other various definitions of low cost housing. UN-HABITAT [2] stated that low cost housing definition 'depends greatly on the economic capacity of the target group' and every country has its own characteristics of affordability, thus each of the definition is different from one another.

Low cost housing is not new in Malaysia. The reason of providing low cost houses to low income group in Malaysia is to ensure that this group gets greater access to adequate and affordable shelter and related facilities.

The objective of this paper is to propose a redevelopment of the Riffle Range Flat in order to provide a better quality of life for people living in low cost housing. The main area of discussion includes incorporating IBS modular system in the new development by creating various possibilities and versatility of arranging units to overcome the monotonous look and also providing more units to the residents. The study also proposed ways for a more conducive living with provisions of recreational and community spaces. Other than that, sustainable issues such as the usage of recycle materials as well as adapting old infrastructures in this urban renewal scheme is hoped to benefit the community and other stakeholders effectively.

\section{Literature review}

The literature review covers the overview of low cost housing in Malaysia, IBS in solving housing problems and sustainability.

\subsection{Low cost housing in Malaysia}

According to Malaysia's Ministry of Housing and Local Government, low cost housing are initiated for the low income group with household income not exceeding RM1500, and house price ranging from RM25,000 to RM42,000. The policy specifies that each low cost house (terrace houses or flats) must have a minimum built-up area of 650 sq. ft. consisting of bedrooms, a living room, a kitchen and a bathroom.

The problems of low cost housing in Malaysia includes: low construction quality, unhygienic, bad delivery system, insufficient provision for social 
amenities, non- conducive environment, high crime rate and insufficient parking facilities. The image is bad and often associated with vandalism.

Ghani and Lee [3] highlighted that Malaysian government has taken the initiatives to provide low cost housing starting from the First Malaysian Plan (1966-1970). The objective is to provide adequate and affordable housing to the low income groups. Private sector invested in this during the Second Malaysian Plan (1971-1975), when the government realized their importance in order to achieve adequate housing supply target.

However, until today there are still problem of demand- supply on low cost housing in Malaysia. The supplies were way behind the demand, despite the target set every 5 years over the last four decades. In order to increase the number of low cost housing, the government has imposed a requirement for private sectors to include $30 \%$ quota provision of low cost housing in every residential development.

The Malaysian Government under its Tenth Malaysian Plan (2011-2015) targets to improve this problem by providing 78,000 new affordable housing units. Other than that, another RM500 million fund was also allocated for repairing and maintaining current private and public low cost housing [4]. The Government will also look into the possibilities of giving incentive such as tax relief for buildings and design which are environmental friendly incorporating green design features.

Recently, the National Housing Department launched the National Housing Policy (NHP) on 10 February 2011 which delineates a clear direction on housing development in Malaysia. It is aimed 'to provide accessible, adequate, affordable and quality housing for all Malaysians, particularly the low-income group' [5]. The usage of most recent technology and devices such as IBS and knowledge sharing from other countries are encouraged. Sustainability issue was explained in Thrust 5 of NHP, on the usage of green technology especially in design scheme, usage of recyclable materials and development of smart building. Thus, NHP is expected to solve various problems normally associated with housing with the commitment of all parties in the industry.

\subsection{IBS in solving housing problem}

A variety of definitions on the term Industrialized Building System (IBS) have been suggested. According to Esa and Nuruddin [6], IBS is a stage starting from usage of construction workers to a system that make use of factory production in order to reduce wastage of resources and increase value of end users. Warszawski [7] described IBS as unified elements which work together to allow certain performance of a building.

The Construction Industry Development Board (CIDB) of Malaysia defined IBS as 'a construction system in which components are manufactured in a factory, on or off site, positioned and assembled into a structure with minimal additional site works' [8]. This system helps reduce the dependency on foreign labour as building elements such as wall, floor slab, beams and others are prefabricated off-site. The assembly of building elements will be done when the components are brought to site. 
IBS was first introduced in Malaysia in early 1960s [9]. Back then, the Ministry of Housing and Local Government of Malaysia visited a number of European countries and assessed their housing development program. The pioneer of IBS project was the Pekeliling Flat in Jalan Pekeliling, Kuala Lumpur which consisted of several blocks of low cost housing. In order to overcome the increasing demands of housing, the development has to be high rise blocks. Building was designed based on the necessity at that time with very little consideration on aesthetics. It was very monotonous, plain looking building using pre-cast concrete wall panel and plank slabs. The second IBS project was the Riffle Range Flat in Penang. Generally, the reason of using IBS was to speed up delivery time and built affordable and quality houses. Apart from this, it minimizes resource wastage, reduce site activities, and control quality of project.

Since then, a number of projects have used IBS system to speed up construction period. In 2003, the Government through the Construction Industry Development Board (CIDB) [10] has launched IBS Roadmap 2003-2010 to promote and encourage the usage of IBS in Malaysia especially for the construction of Government quarters. The recent CIDB [11] IBS Roadmap 20112015 mission is 'to provide a quality, efficient, competent and sustainable IBS industry that contributes to the competitiveness of Malaysia's construction sector'. The Government has made it mandatory for all public and private sectors involved people's housing project to employ at least 70\% IBS contents.

\subsection{Housing and sustainability}

Sustainable development is defined in Brundtland Report [12] as 'meeting the need of the present without compromising the ability of future generations to meet their own needs'. It relates very much to the need to balance our act, giving equal rights and sharing what we have now with the future generation. The Rio Declaration on Environment and Development [13] in its principles highlighted that sustainable development must be a balance combination of three interrelated aspects: environmental protection, economic growth and social development.

Ebsen and Rambol [14] stated that sustainable urban housing need to integrate energy and environment issues in the housing program. They further explained that certain issues need to be considered: economical sustainability, environmental sustainability, technological sustainability, socio-cultural sustainability and organizational sustainability. Economical sustainability depends on the affordability of the target group while environmental sustainability relates on sustainable building materials, usage of renewable energy and giving minimum impact to local environment. Technological sustainability refers to suitable technology which is economical, require minimum repair and maintenance and fit the local condition. Socio- cultural sustainability involves design in which could correspond to the user's way of life. Organizational sustainability refers to controlled organisational set-up from the initial stage of project until after the project has been completed. The integration of these five issues is important and need to be incorporated to achieve a holistic sustainable urban housing. 
So far, there has been limited discussion on IBS and sustainability. Ismail [15] stated that there are three split strategies for IBS to achieve sustainability and green construction namely industrial, flexibility and demountability. Industrial strategies include the capability of reducing cost, time and materials, which could be in the form of using Modular Coordination and others. Flexibility includes the adaptability of services piping to be located at numerous locations such as toilets and kitchens. Finally, demountability strategy deals with replacement of building components with different life time in different scale such as using standardize design, building materials and others.

The image of IBS is supposed to be green and environmental friendly with clean environment and sustainable construction. There is a clear trend that the Malaysian government is promoting sustainable development. It was repeatedly being mentioned and publicized nationwide. One question that need to be asked however, is whether housing projects in Malaysia are really into sustainability as a whole or just a mere development without any intrinsic values.

\section{Methodology}

The methodology used is synoptic method where analysis was done to search for alternatives and their comparison. Initial data were obtained from site observation to help determine the parameters for this intervention project.

\section{Redevelopment site: Riffle range flat, Pulau Pinang, Malaysia}

The proposed site is located on Lot 1268, 1275-1283, 2022 and 2104 (fig. 1), Section 2, Jalan Padang Tembak, North East District of Georgetown in Penang. It is better known as Riffle Range Flats, as the site was used for target practices back in 1950s. The area is 19.0 acres and is situated at the junction of Jalan Padang Tembak with Jalan Boundary (Jalan Sempadan) and next to the Batu Gantong Chinese Cemetery.

It consist of 6 blocks of 17 storey and 3 blocks of 18 storeys flats. It was built in 1969, containing 3,682 residential units and 62 shop lots. The privately owned blocks were very flat and plain looking dwellings, packed with around 15,000 occupants. There are also 7 blocks of 4 storey walk-up apartments, owned by the Penang Municipal Council which is located on Lots 2022 and 2104 with 114 units. The units were very small, ranging from approximately $36 \mathrm{sq} . \mathrm{m}$ (for one bedroom units) to 38.7 sq. $\mathrm{m}$ (for 2 bedroom units).

Among the problems in Riffle Range Flat are insufficient number of car parks, illegal hawkers alongside main road which create unsafe and unpleasant environment, no proper space for community and cultural activities, improper sanitation, rubbish management which created bad odour and unhealthy environment, high crime rate and insufficient landscape and recreational area. Therefore, this research will culminate into design proposals to create a more conducive living by enhancing the character of Riffle Range and regenerate the whole development. 

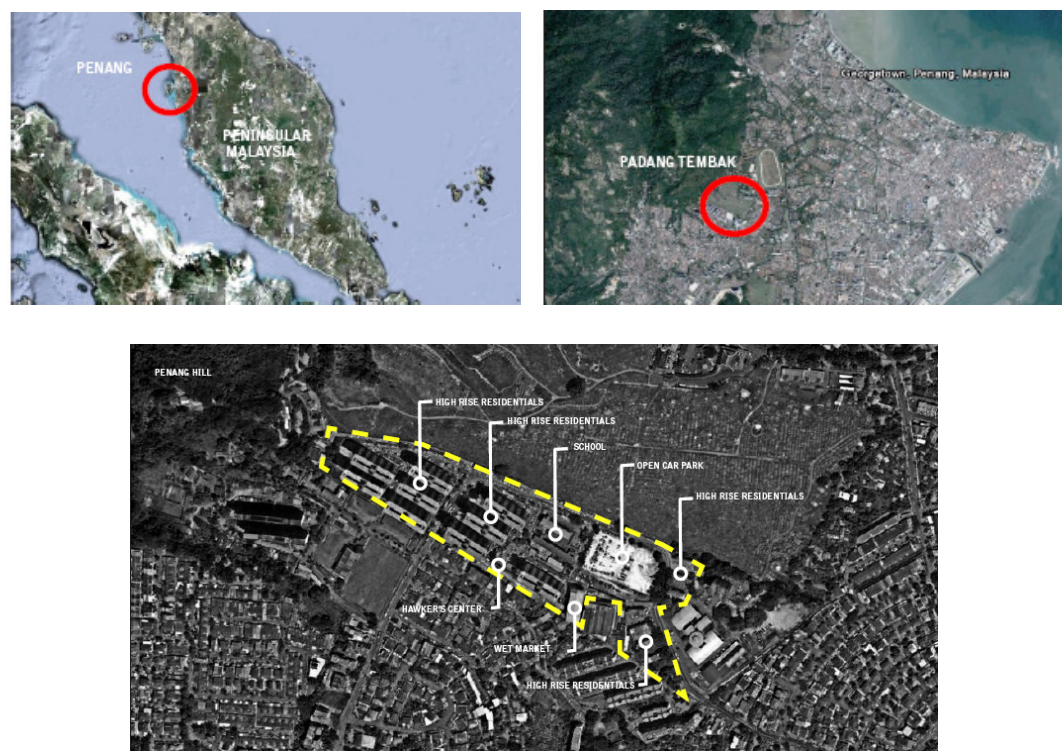

Figure 1: The location of Riffle range flat, Penang, Malaysia.

\section{Results and discussion}

The following discussions are based on the issues identified and analysed on the identified site during the initial study. The concept for the design is generated from the strategies identified during the design process. It is a proposal on how a better quality of living conditions could be achieved through the usage of IBS and sustainability concept.

\subsection{Design strategies}

The main priority for the redevelopment is by projecting a new image, emphasizing cultural diversity and the unique character of the site.

The proposed redevelopment project is divided into four stages (fig. 2). In order to enhance the Rifle Range community life, new residential units were proposed, existing residential buildings are to be refurbished and sufficient community and health care center are to be built. Gross floor area of existing blocks was maintained to preserve the activities and street pattern of the existing development. The overall layout of the new residential units have to be modified with certain elements remained from the existing buildings. The new residential units include 3 bedrooms (area of $78 \mathrm{sq} . \mathrm{m}$ ) and 2 bedrooms (area increased from 38.7 sq. $\mathrm{m}$ to 75.4 sq. $\mathrm{m}$ ) for elderly couple tenants. The 1 bedroom units were omitted as it is too small and not suitable for the occupants.

Figure 3 illustrates the design strategies for the redevelopment project. The lack of parking spaces was overcome by providing additional car parks to residential blocks. In terms of image, the new proposal tried to break away from 


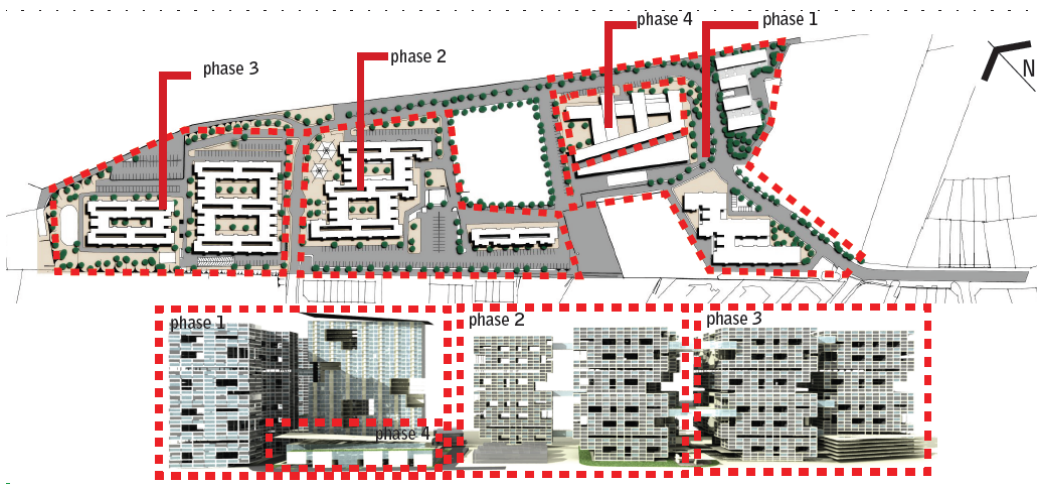

Figure 2: $\quad$ Indication of phase 1 to phase 4 of the new redevelopment.

1. Car parks

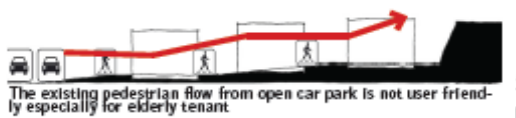

The additional car park will be prorided at each blocks to solve the problems

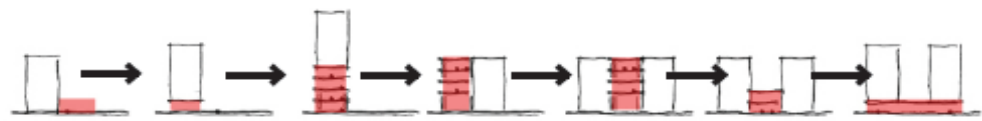

The Installation of additional car parks will be detached by two existing blocks. The first and second floor will be demolished and the new structure will be constructed.

2. Image block

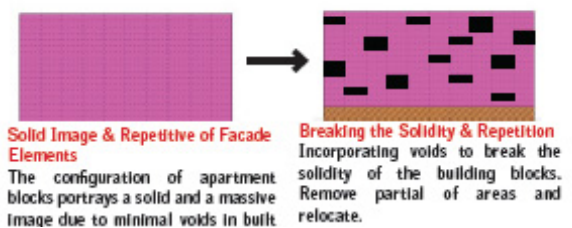

3. Fine gralned/ catalyst commerclal/shop

hawkers

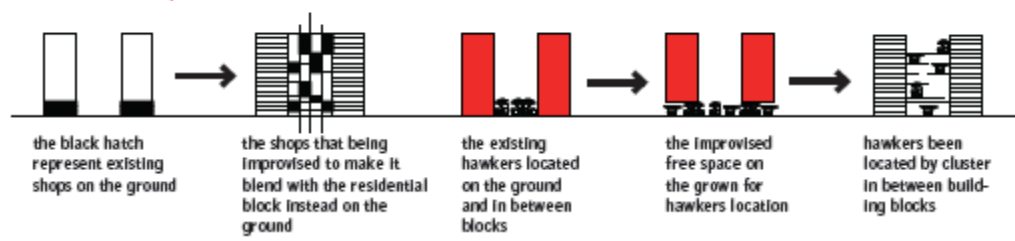

4. Odour / ventllation
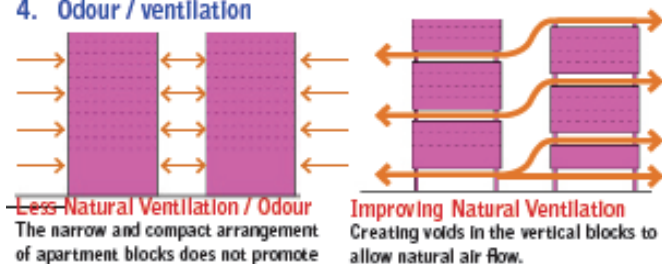

Improwing Natural Ventllation

Creating voids in the vertical blocks to

allow natural air flow.

Figure 3: Design strategies of the proposed scheme. 
solid, plain, dull- looking facade by incorporating voids to break the solid and repetitive appearance. Concept of 'porosity' which normally associated with something easy to penetrate, easily accessible, open, easy to flow, interacting and inviting was introduced. The idea allows large number of openings and passages rather than solid form. It creates interesting lighting effects through form, shade and shadow. Hawkers were also relocated in clusters between residential blocks. In order to improve natural ventilation, voids were created on vertical blocks to allow more natural air flow through the buildings.

Phase 1 (fig. 4) is to be completed in 48 weeks where it will be a new development of residential and commercial spaces. It will provide temporary shelter for existing flat residents.
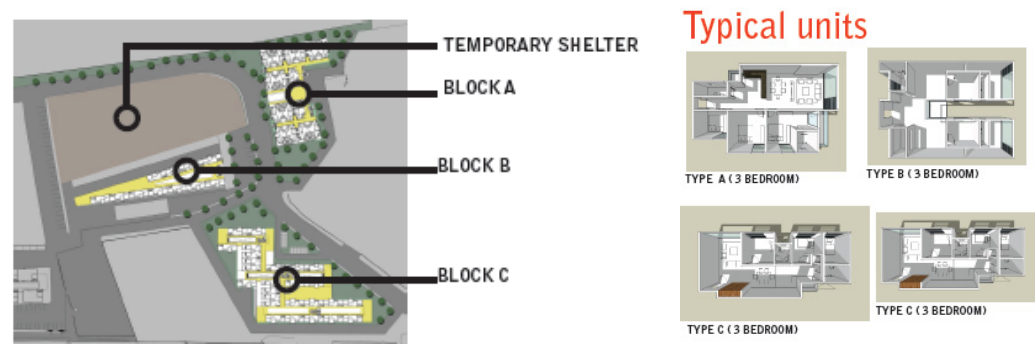

Figure 4: $\quad$ Proposal for phase 1.

Phase 2 (fig. 5) is to be completed in 48 weeks where the schedule of work is as follows: to reassemble wall on adjacent flat, reinforcement of new structure for the block and refurbishment of open spaces. Upon completion, residents of the unfurbished flats are relocated to the new completed buildings with further refurbishing works on the new food courts for the former street hawkers.
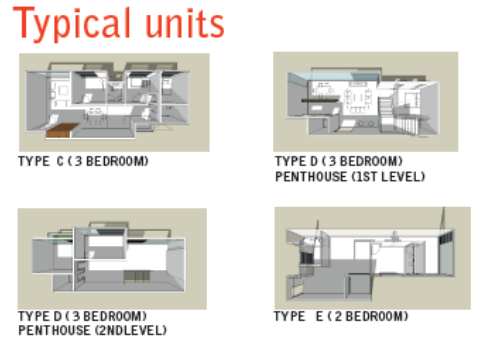

Figure 5: $\quad$ Proposal for phase 2.

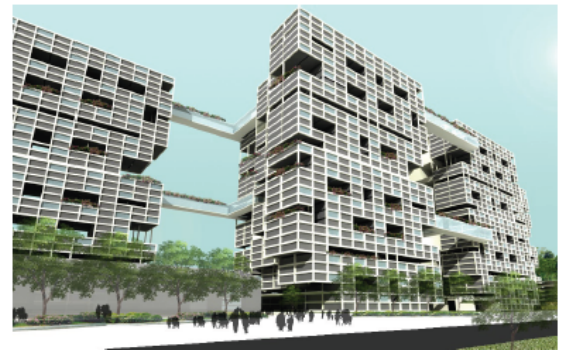

Phase 3 (fig. 6) is to be completed in 64 weeks where the schedule of works are as follows: to reassemble the walls on the existing flat, refurbishment and construction of new structures for the blocks, and finally relocating the residents from the old flats to their new refurbished units.

Phase 4 (fig. 7) is to be completed in 16 weeks where works will be on the new development of community and healthcare center. 

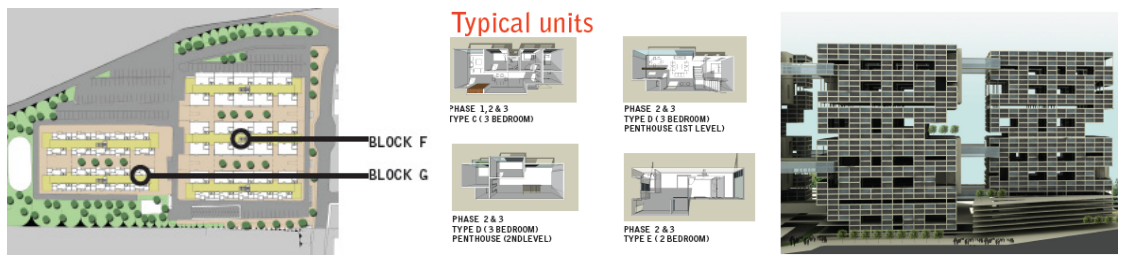

Figure 6: $\quad$ Proposal for phase 3.
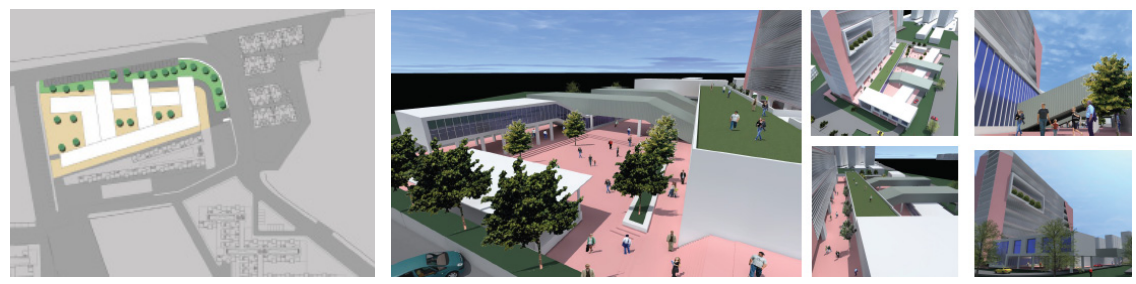

Figure 7: $\quad$ Proposal for phase 4.

The regeneration of Riffle Range Flats will benefit the whole community also contributes to a sustainable place-making within the context of the city of Georgetown.

\subsection{Method of construction}

IBS is incorporated in the proposed development due to its flexibility in adapting and reusing existing infrastructure to accommodate new units. IBS aimed to high speed up construction and therefore wastage is kept to a minimum. This will lead to less environmental impact created and less exposure to damage during construction stage. The system also allows efficiency during construction period where many of the residents are living in the shelter area provided.

Modular Coordination (MC) is one of the elements of IBS to be incorporated in the proposed scheme. Using MC, all components will be standardized for production. It includes certain reference to common modular grids with minimal tolerance allowed. The system provides versatility in composing housing units to enhance the facade treatment and generate 38\% more units than the existing number. The new development will start from demolishing the old residential building, followed by erecting new structural framework on the existing ground floor area. New modular units will be slotted into the framework and finally the additional modular unit will be slotted at the main block. The modular units enable the increase of number of residential unit. The system (fig. 8) is also flexible to accommodate additional number of tenants in future. 


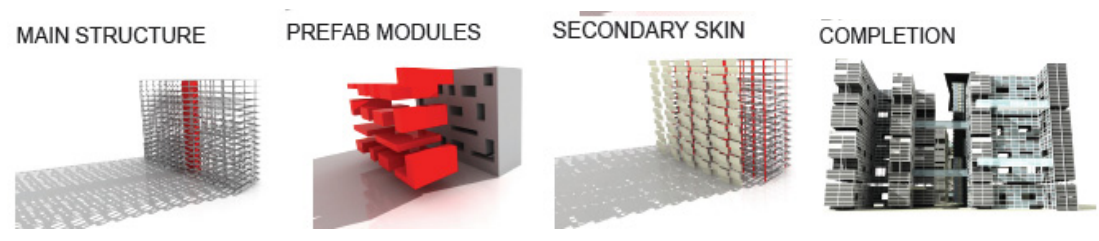

Figure 8: $\quad$ Sequence of construction using IBS system.

Prefabricated structural and non- structural elements will be used to achieve speed in construction process at the site which has a lot of constraints. Architectural installation will be made of various modular components. Only affected parts, including the internal built-in, will need to be replaced in future rather than having to change the entire installation. It also allows flexibility in terms of design so that monotonous and dull looking buildings can be avoided.

\subsection{Sustainable strategies}

To achieve sustainable development in the proposed scheme, all the five components: economical, environmental, technological, socio-cultural and organizational must be embedded in the program. By using sustainable geometric form (with the square grid of $15000 \mathrm{~mm}, 5000 \mathrm{~mm}$ and $3200 \mathrm{~mm}$ ), the design of residential blocks can have more efficient spaces, less wastage in construction and have shorter construction period. The project aimed for recyclable finishes, greener products countries are to be used for lesser processing and transportation cost. Only local materials from Malaysia or neighbouring countries are to be used for lesser processing and transportation cost.

Other than that, the sustainable strategies (fig. 9) also include:

i. Collection of rainwater and storm water: A strategy to collect rainwater at rooftop and storm water from surface run- off. A collection of rainwater will be used for irrigation at sky gardens, whereas the storm water will be used for cleaning of common areas.

ii. Horticulture: This includes the supply of seeds and recycled compost soils from dwellers food waste to encourage farming at gardens. Indigenous vegetations include 'cal xin', chives, basil, 'bai chai', green leaf lettuce, floriculture, orchids and ornamental plants.

iii. Photovoltaics: The usage of photovoltaics panels to capture daylight energy for the photosynthesis process of vegetation at sky garden. This could overcome the problem of insufficient sunlight based on the simulation of shadow from surrounding buildings.

iv. Eco-decks: Supply of seed and recycled compost soil from dwellers food waste to encourage farming at the gardens and gives a more pleasant view.

v. Garbage disposal: Implementation of garbage grinder at all kitchen sinks. This is convenient for dwellers in disposing food waste, at the same time 
recycling food waste into composite soil for farming and landscaping used.

vi. Sun louvers: Installation of adjustable louvers that changes its shading according to weather and also for privacy control.

vii. Vertical green: Position of hanging vine within the central void to reduce heat conduction and solar radiation.

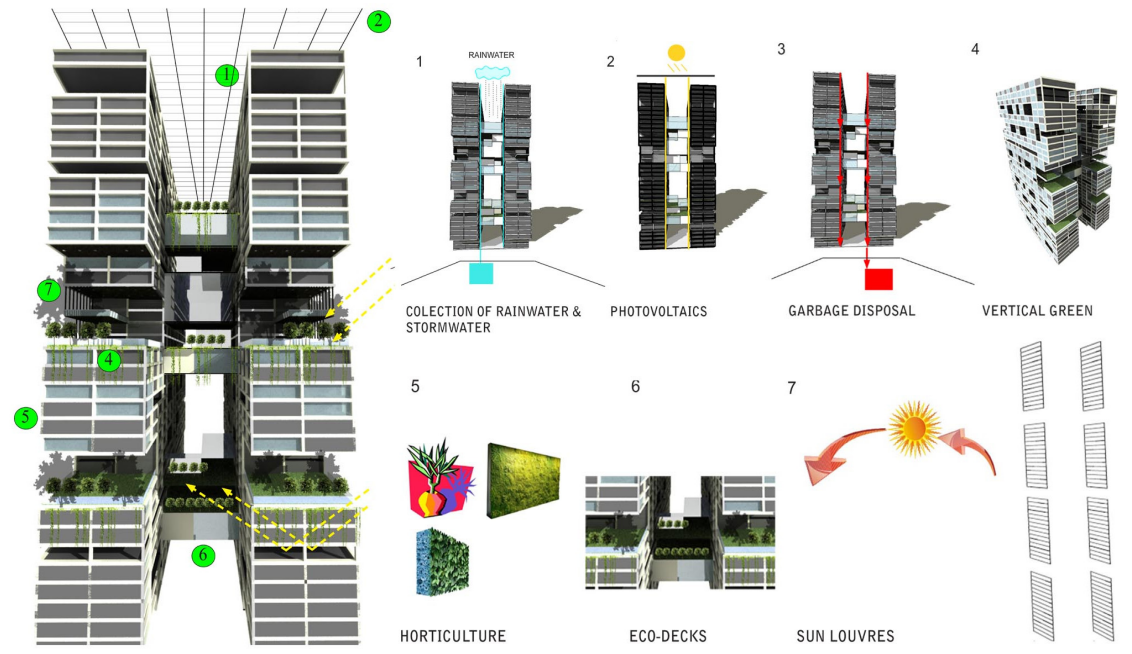

Figure 9: $\quad$ Sustainable strategies.

\section{Conclusion}

Low cost housing can be made affordable and at the same time aesthetically pleasing to all. It should be a fair shelter for the low income people to enjoy living in. This paper has provided a fair account on the use of IBS for reducing cost and time for construction. It also outlined the strategies required in order to achieve a sustainable development providing a more vibrant, comfortable and safe environment for people to live. It consists of design proposal with a lot of potentials to achieve a better quality of life in an urban setting. The implementation has yet to be done but the success of this new proposal depends on how well it is being implemented from the beginning of the design stage until after the completion of the project.

\section{Acknowledgements}

We would like to thank the students of the UDRL (Urban Design Research Lab) especially Nurulain Zainuddin, Ahmad Kamel Muhamad, Ali Hakim Zakaria, Aishah Abdul Manap Khalid, Nur Zahira Mohamad Zani and Nur Hani Ahmad Pakhri for the assistance in completion of this paper. 


\section{References}

[1] Istanbul Declaration on Human Settlement, 1996, http://ww2.unhabitat.org/declarations/Istanbul_Declaration

[2] UN-HABITAT, Low Cost sustainable Housing, Materials + Building Technology in Developing Countries. Shelter Initiatives for Climate Change Mitigation (SICCM), 2008.

[3] Ghani, S. and Lee, L.M., Low Cost Housing in Malaysia. Utusan Publications and Distributors: Kuala Lumpur, 1997.

[4] Malaysian Government, Tenth Malaysia Plan, Percetakan Nasional Berhad: Kuala Lumpur 2011.

[5] National Housing Department, National Housing Policy, Ministry of Housing and Local Government: Kuala Lumpur, 2011.

[6] Esa, H. and Nuruddin, M.M, Policy on Industrialised Building System. Colloquium on Industrialised Construction Systems, Kuala Lumpur, 1998.

[7] Warszawski, A., Industrialized and Automated Building System. E \& FN Spoon: Technion-Israel Institute of Technology, 1999.

[8] CIDB Malaysia, Manual for Assessment of Industrialised Building System, CIDB: Kuala Lumpur, 2001.

[9] Thanoon, W. A. M., Peng, L. W., Abdul Kadir, M. R., Jaafar, M.S. and Salit, M.S., The Experiences of Malaysia and Other Countries in Industrialised Building System in Malaysia, Proceeding on IBS Seminar, UPM, Malaysia, 2003.

[10] CIDB, IBS Roadmap (2003-2010). Construction Industry Development Board (CIDB): Kuala Lumpur, 2003.

[11] CIDB, IBS Roadmap (2011-2015). Construction Industry Development Board (CIDB): Kuala Lumpur, 2011.

[12] Brundtland Report: Our Common Future, United Nations World Commission on Environment and Development. http://en.wikisource.org /wiki/Brundtland_Report

[13] The Rio Declaration on Environment and Development, http://www.unescap.org/esd/environment/rio20pages/Download/ Rio_Declaration-E.pdf

[14] Ebsen, C. and Rambol, B., International Review of Sustainable Low-Cost Housing Projects, Proceedings: Strategies for a Sustainable Built Environment. Pretoria, 23-25 August 2000, 2000.

[15] Ismail, Z., Industrialised Building System (IBS) for Sustainability and Green Construction. http://ibsresearch.blogspot.com 